\title{
AOIR
}

Selected Papers of \#AoIR2020:

The $21^{\text {st }}$ Annual Conference of the

Association of Internet Researchers

Virtual Event / 27-31 October 2020

\section{THE MEMEIFICATION OF \#SCHOOLSHOOTINGS IN THE U.S.: YOUTH, TIKTOK, AND THE PLAYFUL MEDIATED BODY}

\author{
Jacqueline Ryan Vickery
}

University of North Texas

With active shooter drills as a normal part of student experiences in the U.S., the threat of a school shooting has become commonplace and institutionalized. Within a context of cultural trauma, it is no surprise that teens are using digital media to create spaces for sense-making and as a way to respond to the constant threat of violence. School shootings are thus doubly memetic: both the actual phenomenon of school shootings and the media texts are "contagious patterns of cultural information" (Knobel and Lankshear, 2007, p. 199) that are repetitive, replicable, malleable, and polysemic; both "directly generate and shape the mindsets and significant forms of behavior and actions of a social group" (ibid.). Focusing on the mediated memeification of school shootings, there exists an entire genre of \#darkhumor videos on TikTok in which young people create and circulate irreverent humorous media texts as a response to the constant threat of - and perceived political inaction to - school shootings in the U.S. ${ }^{1}$ Through an analysis of teens' \#darkhumor school shooting videos on TikTok, this paper asks: what can we learn about how young people understand cultural trauma through an examination of their playful and memetic social media practices?

\section{Critical Framework: The Mediated Playful Body}

Drawing from theoretical understandings of play as a pleasurable communicative power for experimenting with adult/societal norms and structures that blur boundaries between reality and imagination (Parnell and Patsarika, 2014), I consider how the memetic nature of TikTok videos - as social modes of production and as socially mediated texts

\footnotetext{
1 The videos frequently acknowledge the cultural specificity of school shootings as a uniquely U.S. phenomenon.

Suggested Citation (APA): Vickery, Jacqueline Ryan. (2020, October 28-31). The memeification of \#schoolshootings in the U.S.: youth, TikTok, and the playful mediated body. Paper presented at AolR 2020: The $21^{\text {st }}$ Annual Conference of the Association of Internet Researchers. Virtual: AolR. Retrieved from http://spir.aoir.org.
} 
- are a way for young people to use their bodies and the technosocial affordances of social media to playfully experiment with and subvert cultural discourses and norms. The "carnivalization" (Bakhtin, 1984) and irrational absurdity of turning generationallyspecific tragedy, cultural trauma, and the "tragic sense" (Warnick, Johnson, and Rocha, 2010) into irreverent memes demonstrates a response to and engagement with larger cultural discourses that structure young people's spaces (specifically school) and identification with their peers.

The replicability and mutability of memes as a central digital artefact in participatory culture opens up possibilities for play, subversion, the personalization of politics, and collective affect (Author, 2014; Highfield, 2017). Primarily a music video app, the "platform vernacular" of TikTok (Gibbs et al., 2015) centers performativity and the body as the locus of memeification; in the videos, the teens' bodies "become both the medium of the meme and its message" (Shifman, 2012; p. 200). The genre of \#darkhumor \#schoolshooting videos are an acknowledgement of trauma - and the ways in which school shootings violate both childhood and schools as sites of protection - but in ways that are playful, irreverent, humorous, and inherently corporeal. The affective performances and "videos of affinity" (Lange, 2009) that are evident in the production and circulation of the memes are indicative of generational coping strategies. While the playful and irreverent videos can be read through a lens of critique, satire, or parody (Buckingham, 2003; Highfield, 2017), the memetic, social, corporeal, and performative nature of TikTok affords related yet distinct practices and modes of playful social engagement that I refer to as the mediated playful body.

\section{Methodology and Sample}

After an initial search for TikTok videos using the hashtag or combination of hashtags \#darkhumor, \#schoolshooting(s), and \#schoolshooter(s), I identified four sound clips ${ }^{2}$ that young people frequently use to memeify school shootings with patterns of mimicry and repetition. A sample of 200 videos that used one of the four sound clips in combination with the hashtags were chosen for a multi-methodological analysis which involves: 1) coding the videos for a descriptive content analysis, ${ }^{3}$ and 2) a discursive analysis of the memetic narrative and visual elements of the video. Although the sample cannot account for all potential videos and is not intended to be representative, for the sake of this qualitative analysis I believe it sufficiently captures a diverse sample of a memetic trend and phenomenon that is situated within a specific social practice and specific temporal context related to teens' perceptions of school shootings in the U.S.

\section{Findings}

\section{School and Placemaking Practices}

Coding for the content analysis is still in progress; the purpose is to reveal not only who is making the videos, but also to identify how gender, ethnicity, and location shape the

\footnotetext{
2 Songs Pumped Up Kicks (Foster the People) and Bulletproof (La Roux); sound clips known as gett0 and sophienator3000.

${ }^{3}$ Videos are coded for gender and ethnicity of the participants, the filming location, the number of participants, and for the presence of adults
} 
memetic practices and "vernacular creativity" (Burgess, 2008) of who is allowed to participate in irreverent \#darkhumor \#schoolshooting videos and in what ways. Of note thus far, a large sample of the videos are produced at what reasonably appears to be schools, with many filmed in bathrooms, hallways, and classrooms. The creation of irreverent playful media in the very spaces that are constructed as potential sites of trauma demonstrates a re-appropriation of space and collective placemaking practices (Halegoua, 2020). Rather than ceding school as a site of potential violence, students are coping by expressing a sense of fear masked as pleasure and sociality through the reclamation of space.

\section{Visual and Discursive Analysis}

There are at least three genres of \#schoolshooting meme videos that I have identified which can be organized alongside two intersecting axes: the use of particular memetic themes (e.g. narratives, tropes, music, visuals) and their memetic function (e.g. parody, critique, coping). The first category is playful parodies of media stereotypes and tropes, the second is playful critiques of the absurdity of school violence, and the third is playful coping through dance and movement. Although there are variations of these different memes, as will be discussed, they each use playful mediated bodies to corporally engage with the replication, mutability, and fidelity of the polysemic meme. The memes reveal an acknowledgement and critique of adult-centric and neoliberal narratives that attempt to individualize and "make sense of" the absurdity of violence at school.

\section{Playful Parody: Stereotypes and Transactional Survival}

Playful parody videos replicate, satirize, or mock mediated stereotypes of the "lone wolf shooter" whom the video creators depict and label as the "weird kid" or "quiet kid" at school. The videos humorously depict transactional relationships in which the video's producer tries to befriend the "weird kid" as a means of survival. Girls demonstrate an awareness of and humorous response to the power of their sexuality to mitigate their own vulnerability (i.e. trading sex for survival). Boys in the videos are more likely to safeguard their survival by trading intellect or social status (i.e. "nerds" are saved by sharing homework and "cool" kids are saved by extending social invitations). The videos simultaneously disavow and uphold relationships as transactional protections against violence. The meme reveals young people's awareness and internalization of gendered tropes and discourse that insinuate that it is the responsibility of teens to confer the sexual or social status of the shooter, lest they be held responsible for their own victimization.

\section{Playful Critique: Absurdity of School Violence and the Failure of Neoliberal Responses}

The second meme depicts teens sarcastically mocking school and market "solutions" to the ever-present threat of school shootings: name badges, clear backpacks, and/or bulletproof backpacks. Portraying "individualized solutions" rather than an engagement with systemic failures or structural changes are endemic of the neoliberal critique young people leverage. While these videos may be read as inappropriate, dark, or crass it is the very absurdity of the memes that sheds light on the equally - and arguably 
exponentially more - absurd responses by adults and policymakers that have failed to safeguard children's protection and well-being.

\section{Playful Coping: Celebratory Distractions}

The third genre involves students dancing as a means of celebration. The dances can be either spontaneous or choreographed responses to hypothetical shooting scenarios, actual campus lockdowns, or responses to credible threats that result in temporary school closures. The dances exhibit knowledge of both the platform logics of TikTok and a creative vernacular of using the body to express emotions that students may not have the language to express. The body becomes a stand in for affect and emotion, as well as a mode of peer identification through memetic dances. Students temporarily transgress norms of classroom decorum and space, thus paralleling the ways violence also violates the boundaries of school and safety. Cultural trauma gets codified as play and the playful mediated body serves as a coping mechanism in the face of unspeakable trauma.

\section{Conclusion}

Although the videos are intended to be humorous or irreverent, the performative and social affordances of TikTok and the mediated playful body emphasize play as a communicative expression of cultural and generationally-specific trauma and affords young people opportunities for collective sense-making via playful peer identifications.

\section{References}

Author, 2014.

Bakhtin, M. (1984). Problems of Dostoevsky's Poetics. Minneapolis: University of Minnesota Press.

Buckingham, D. (2003). Pedagogy, parody and political correctness. In D. Buckingham (Ed.), Teaching Popular Culture: Beyond Radical Pedagogy, 63-87.Routledge.

Burgess, J. (2008). 'All your chocolate rain are belong to us?' Viral video, YouTube and the dynamics of participatory culture. In G. Lovink and S. Niederer (Eds.), Video Vortex Reader: Responses to YouTube (pp. 101-109). Institute of Network Cultures.

Gibbs, M., Meese, J., Arnold, M., Nansen, B., \& Carter, M. (2015). \#Funeral and Instagram: Death, social media, and platform vernacular. Information, Communication \& Society, 18(3), 255-268.

Halegoua, G. R. (2020). The Digital City: Media and the Social Production of Place. NYU Press.

Highfield, T. (2017). Social Media and Everyday Politics. John Wiley \& Sons.

Knobel, M., \& Lankshear, C. (2007). New literacies: Everyday Practices \& Classroom Learning. Open University Press.

Lange, PG (2009) Videos of affinity on YouTube. In P. Snickars and P. Vonderau (Eds.) The YouTube Reader, 228-247, Stockholm: Wallflower Press.

Parnell, R., \& Patsarika, M. (2014). Playful voices in participatory design. In C. Burke, and K. Jones, K. (Eds.), Education, Childhood and Anarchism: Talking Colin Ward, 125-136. Routledge. 
Shifman, L. (2012). An anatomy of a YouTube meme. New Media \& Society, 14(2), 187203.

Warnick, B. R., Johnson, B. A., \& Rocha, S. (2010). Tragedy and the meaning of school shootings. Educational Theory, 60(3), 371-390. 